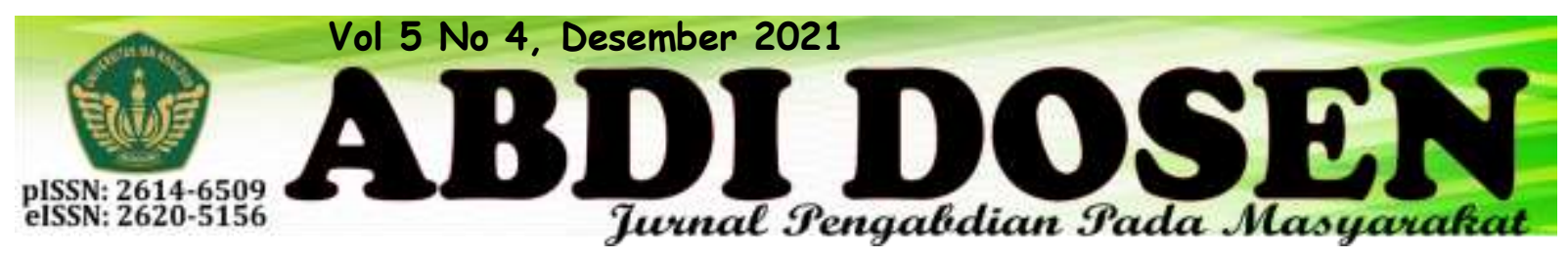

\title{
EDUKASI KELOMPOK WANITA TANI MENGENAI SISTEM PENJUALAN DAN PENDISTRIBUSIAN HASIL PRODUKSI GREENHOUSE HIDROPONIK DESA PENEBEL
}

\author{
Dewa Ayu Putu Adhiya Garini Putri ${ }^{1}$, Kadek Devi Kalfika Anggria Wardani ${ }^{2}$ \\ Adie Wahyudi Oktavia Gama ${ }^{3}$, Gusi Putu Lestara Permana ${ }^{4}$ \\ adhiyagariniputri@undiknas.ac.id ${ }^{1}$, devikalfika@undiknas.ac.id ${ }^{2}$, adiewahyudi@undiknas.ac.id ${ }^{3}$, \\ lestarapermana@undiknas.ac.id ${ }^{4}$ \\ Fakultas Teknik dan Informatika, Universitas Pendidikan Nasional ${ }^{1,3}$ \\ Fakultas Ekonomi dan Bisnis, Universitas Pendidikan Nasional ${ }^{2,4}$
}

\begin{abstract}
ABSTRAK
Saat ini Desa Penebel merupakan salah satu desa yang fokus dalam pembangunan desa yang berbasis ekologi. Desa penebel berperan aktif untuk mendukung ketahanan pangan rumah tangga, salah satunya dengan membentuk Kelompok Wanita Tani (KWT). KWT Desa Penebel dibentuk sebagai salah satu organisasi yang berletak di Desa Penebel yang tujuannya adalah untuk mengelola hasil pertanian. Metode yang digunakan dalam kegiatan pengabdian masyarakat adalah kegiatan sosialisasi dan pendampingan untuk pembentukan jariangan distribusi hasil pertanian dan pendampingan yang mendukung usaha pemasaran. Berdasarkan hasil eksplorasi kegiatan eksisting, hasil distribusi hasil pertanian yang paling memungkinan adalah saluran distribusi yang berasal dari produsen hingga pengecer. Kegiatan pendistribusian produk tanaman hidroponik juga dibangun melalui media sosial seperti Instagram dan pembuatan logo dan packaging produk dari hasil greenhouse.
\end{abstract}

Kata Kunci : Kelompok wanita tani, penjualan, distribusi

\section{ABSTRACT}

Penebel Village nowadays is one of the villages that focuses on ecological-based village development. Penebel village plays an active role in supporting household food security, one of which is by forming the Women Farmers Group (KWT). KWT Penebel Village was formed as one of the organizations located in Penebel Village whose purpose is to manage agricultural products. The method used in community service activities is socialization and assistance activities for the establishment of a distribution network of agricultural products and assistance that supports marketing efforts. Based on the results of the exploration of existing activities, the most likely distribution of agricultural products is the distribution channel from producers to retailers. The distribution of hydroponic plant products is also built through social media such as Instagram and making logos and product packaging from greenhouse products.

Keyword: Women Farmers Group, sales, distribution 


\section{PENDAHULUAN}

Saat ini Desa Penebel merupakan salah satu desa yang fokus dalam pembangunan desa yang berbasis ekologi. Berbagai kegiatan telah dilakukan untuk mendukung pembangunan desa berbasis ekologi seperti pembangunan tempat pengelolaan sampah terpadu berbasis desa secara mandiri yang digunakan untuk mengelola sampah rumah tangga yang dihasilkan oleh masyarakatnya (Putri et.al, 2020). Selain itu pihak desa juga melakukan berbagai kegiatan diskusi dan sosialisasi kepada masyarakat secara intensif untuk meningkatkan kesadaran masyarakat akan pentingnya menjaga keseimbangan lingkungan.

Secara geografis, Desa Penebel terletak pada ketinggian 300 meter dari permukaan laut yang memiliki potensi daerah agraris yang cukup tinggi dan kecukupan sumber air yang mendukung karena dilalui oleh dua sungai yaitu Sungai Yeh Empas di wilayah Timur dan Sungai Yeh Ho di wilayah Barat (Penebel,2020). Desa penebel berperan aktif untuk mendukung ketahanan pangan rumah

\section{METODE PELAKSANAAN}

Metode yang digunakan dalam kegiatan pengabdian masyarakat adalah pelatihan dan pendampingan sistem distribusi dan branding. Penyuluhan dan pembekalan dilakukan sebanyak 3 kali. Kegiatan pertama dilakukan dengan edukasi KWT terkait edukasi cara pendistribusian hasil panen greenhouse hidroponik. Adapun kegiatan dilakukan dengan dua acara yaitu
1. Kegiatan Sosisalisasi dan pendampingan untuk pembentukan jaringan distribusi hasil pertanian.

2. Kegiatan pendampingan yang tangga, salah satunya dengan membentuk Kelompok Wanita Tani (KWT). KWT Desa Penebel dibentuk sebagai salah satu organisasi yang berletak di Desa Penebel yang tujuannya adalah untuk mengelola hasil pertanian. Selain itu, Desa Penebel bersama dengan tim Lembaga Penelitian dan Pengabdian Masyarakat Universitas Pendidkan Nasional melakukan pengembangan Green Technology dengan pembangunan greenhouse sebagai pilot project untuk mendukung ketahanan pangan di Desa Penebel.

Penanaman pada ruang Greenhouse menggunakan media air dengan tanaman yang dikembangkan adalah beberapa sayuran dan buah-buahan seperti sayuran pokchoy, tomat dan melon. Namun saat ini KWT belum memiliki pengetahuan mengenai sistem pengelolaan dan distribusi hasil pertanian yang belum memadai. Oleh karena itu, tujuan dari kegiatan pengabdian masyarakat ini adalah untuk membantu membangun jejaring distribusi dan sistem penjualan yang dapat diaplikasikan oleh KWT dari hasil Greenhouse.

mendukung usaha pemasaran.

Adapun kegiatan pembentukan chain distribusi hasil pertanian dan kegiatan pemasaran merupakan bagian dari kegiatan pengabdian masayarakat. Kegiatan sosialisasi ini diharapkan dapat membantu memberikan wawasan terkait dengan pola pendistribusian hasil dari greenhouse. Walaupun saat ini proses konsistensi hasil dari greenhouse yang berada di daerah penebel belum signifikan, namun dengan adanya sosialisasi diharapkan membangun pola pikir masyarakat untuk 
mengembangkan melakukan diversifikasi hasil pertanian melalui hidroponik.

Selain itu kegiatan pendampingan dilakukan dengan memberikan informasi secara aktif untuk penggunaan sosial media sebagai salah satu media promosi dan

\section{HASIL dan PEMBAHASAN}

Kegiatan pengabdian masyarakat ini merupakan program yang sedianya dilakukan dalam rangka tindak lanjut dari program Kerjasama yang dilakukan oleh Lembaga Penelitian dan Pengabdian Masyarakat dengan pihak Desa Penebel. Kegiatan awal dilakukan dengan sosialisasi dan edukasi mengenai pembentukan chain distribusi hasil pertanian. Saluran distribusi terdiri dari beberapa tingkatan. Setiap perantara yang melakukan usaha menyalurkan barang kepada pembeli akhir membentuk suatu tingkatan saluran. Produsen maupun pelanggan akhir yang melakukan tugas tersebut.

Kegiatan ini dilakukan dengan pembuatan logo dan perancangan packaging. Kegiatan ini dimaksudkan untuk memberikan identitas produk yang akan di pasarkan sehingga mempermudah branding dari produk yang dihasilkan oleh greenhouse di Desa Penebel.

memberikan pengetahuan kepada KWT sebagai hasil pengelolaan hasil mengenai proses distribusi yang memungkinkan dilakukan. Dari eksplorasi kegiatan eksisting, hasil Distribusi hasil pertanian yang paling memungkinan adalah saluran distribusi yang berasal dari produsen hingga pengecer. Hal ini terkait dengan belum optimalnya hasil yang dihasilkan dari greenhouse sehingga konsistensi produksi belum stabil. Selain itu masyarakat umum masih belum memiliki pengetahuan terkait keunggulan produk greenhouse, sehingga diperlukan sosialisasi terkait pentingnya mengkonsumsi hasil tanaman hidroponik.

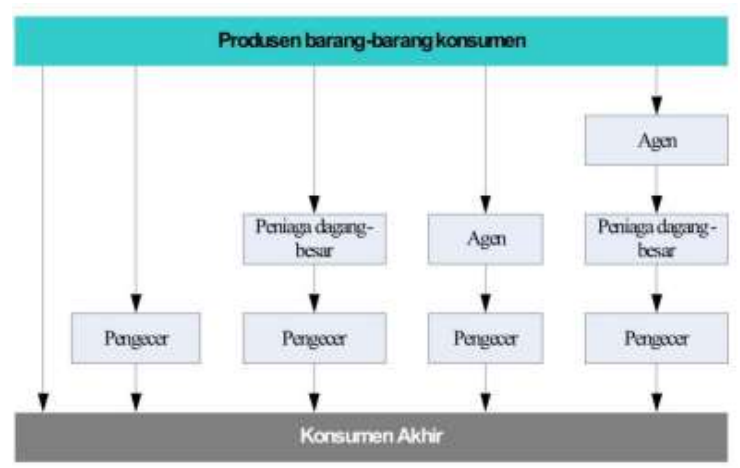

Gambar 1. Tingkat Saluran Distribusi yang paling memungkinkan (Stanton dalam Harjanti, 2015)

Kegiatan selanjutnya dilakukan dengan pendistribusian produk tanaman hidroponik melalui media sosial seperti Instagram. KWT Desa Penebel diberikan wawasan untuk dapat mengoperasikan media sosial dengan tepat guna. Tujuan dari penggunaan media sosial ini adalah untuk memberikan informasi yang lengkap terkait dengan produk yang dihasilkan dari Greenhouse. (Putri, 2015). 


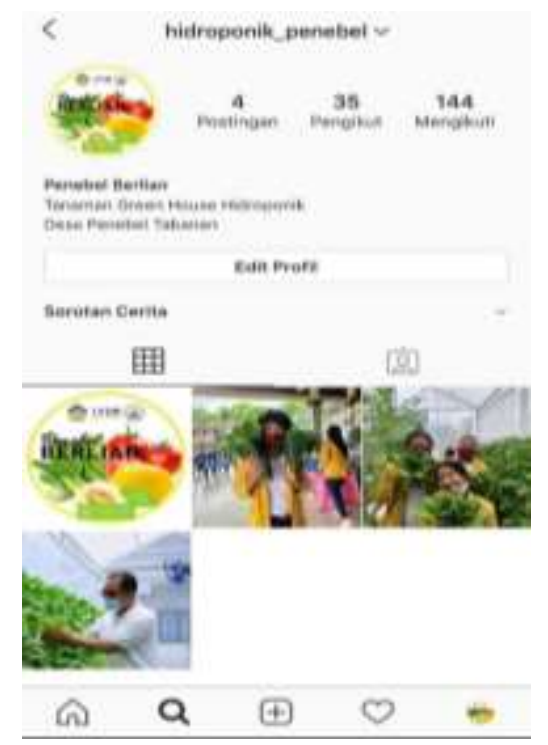

Gambar 2 . Media Sosial yang digunakan dalam upaya pemasaran hasil hidroponik.

Selain itu yang dilakukan adalah pembuatan logo produk dan packaging produk dari hasil greenhouse. Logo adalah elemen grafis yang berbentuk ideogram, symbol, emblem, ikon dan tanda yang digunakan sebagai lambang (Oscario, 2013). Logo Desa Penebel mengusung Tema Penebel Berlian yang merupakan elemen identitas visual yang diharapkan dapat akan mencerminkan kepribadian dan jiwa dari brand tersebut.

Tidak hanya dari logo untuk meningkatkan awareness dari produk yang dihasilkan, hal lainnya yang dapat membantu memberikan daya tarik dari sisi visual adalah kemasan. Saat ini, produk hasil dari greenhouse Desa Penebel belum memiliki kemasan yang memungkinkan untuk pemasaran. Hal ini penting, karena desain kemasan dapat memberikan daya tarik dari sisi visual tentunya (Muckhtar, 2015). Kemasan yang dipilih adalah kemasan plastik dengan logo Penebel Berlian. Pemilihan kemasan plastik ini dianggap yang paling memenuhi dari sisi biaya produksi dan dapat menjaga kesegaran dari produk green house itu sendiri.

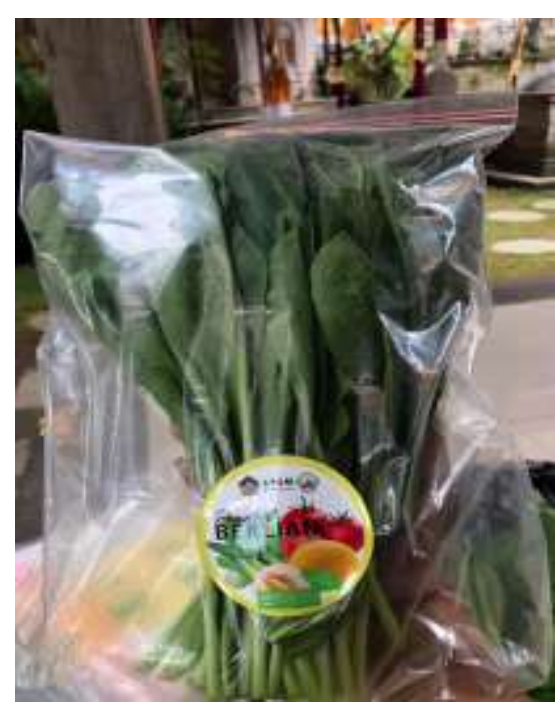

Gambar 3. Kemasan dan Logo dalam upaya pemasaran hasil hidroponik. 


\section{KESIMPULAN}

Hasil kegiatan pengabdian masyarakat di Desa Penebel merupakan salah kegiatan pendampingan dan pemberdayaan masyarakat, khususnya bagi Kelompok Wanita Tani di Desa Penebel.

1. Berdasarkan hasil eksplorasi kegiatan eksisting, hasil Distribusi hasil pertanian yang paling memungkinan adalah saluran distribusi yang berasal dari produsen hingga pengecer.

\section{DAFTAR PUSTAKA}

Harjanti, Intan Muning, Khristiana Dwi Astuti, and Reny Yesiana. 2015. "Pola Distribusi Komoditas Pertanian Unggulan Di Desa Mlatiharjo Kecamatan Gajah Kabupaten Demak."

Tulong, Svide Ridel, Altje L. Tumbel, and Indrie D. Palandeng. 2016. "Identifikasi Saluran Distribusi Dalam Rantai Pasokan Kentang Di Kecamatan Modoinding (Studi Di Desa Linelean)." Jurnal EMBA 4(1): 1562-69.

Putri, Vega Karina Andira. 2018. "Media Sosial Terintegrasi Dalam Komunikasi Pemasaran Brand: Studi Komparasi Pemanfaatan Media
2. Kegiatan pendistribusian produk tanaman hidroponik juga dibangun melalui media sosial seperti Instagram dan pembuatan logo dan packaging produk dari hasil greenhouse. Selain itu kegiatan ini juga membantu masyarakat umum untuk meningkatkan awareness untuk pentingnya mengkonsumsi hasil tanaman organik.

Sosial Oleh High Dan Low Involvement Decision Brand." Jurnal Komunikasi Indonesia 4(2).

Putri, Dewa Ayu Putu Adhiya Garini, and Gusi Putu Lestara Permana. 2021. "Pemberdayaan Masyarakat Melalui Pengelolaan Sampah Berbasis Ecovillage Di Desa Penebel, Kecamatan Penebel, Kabupaten Tabanan, Bali." Journal of Community Development \& Empowerment 1(2): 96-102.

Mukhtar, Sukrianti, and Muhammad Nurif. 2015. "Peranan Packaging Dalam Meningkatkan Hasil Produksi Terhadap Konsumen.” Jurnal Sosial Humaniora 8(2): 181. 